\title{
EDUCATIONAL PRACTICES AND THE RELATIONSHIP BETWEEN PARENTS AND THEIR PREGNANT AND NON-PREGNANT ADOLESCENT DAUGHTERS
}

\author{
Marina Zanella Delatorre' ${ }^{1,2,3}$, Naiana Dapieve Patias, ${ }^{3,4,5}$, Ana Cristina Garcia Dias ${ }^{6,7}$
}

DOI: http://dx.doi.org/10.7322/jhgd.102992

\begin{abstract}
Introduction: Family is an important socialization environment for children, which has influence on adolescent behaviour, and may constitute a risk and/or protection factor on a child's development. Objective: To describe the relationships between parenting practices and the occurrence of pregnancy in adolescents. Methods: Semi-estructured interviews were used with 11 adolescents (5 pregnant and 6 non-pregnant) who were 15 to 19 years old. The Inventário de Estilos Parentais (Parenting Styles Inventory; - PSI) was used to measure the maternal and paternal practices with adolescents. Thematic content analysis was used to analyse the interviews. The PSI was administered as proposed by the manual. Results: There were differences and similarities in the relationships of pregnant and non-pregnant adolescents with their parents. The relationship with the mother seemed to be more positive among young women who did not have a pregnancy experience. There was also more negative maternal child rearing practices among pregnant adolescents as compared to non-pregnant adolescents. However, the relationships with the fathers were similar between the two groups as the fathers' educational practices were negative among both the young pregnant women and the non-pregnant women. Conclusions: Maternal educational practices, but not paternal, seem to be associated with the occurrence of adolescent pregnancy.
\end{abstract}

Key words: education, parents, teens, parenting practices, pregnancy.

\section{INTRODUCTION}

Adolescence is a period in which several physical, psychological and social changes happen in the lives of people. However, the transformations during this period not only affect the teenager who experiences them but also the family as a whole. The new adolescent's demands and behaviours as well as the need for independence and greater involvement with their peers can be a detriment to the family. As such, family functioning patterns require reorganization ${ }^{1}$.

When changes in these patterns do not happen, favourable conditions are established for the emergence of various family conflicts, especially between parents and children. ${ }^{2}$ The adaptation of the family requires that the parental authority is balanced and flexible in order to allow the teenager to experience their independence and, at the same time, be able to rely on the guidance and protection of the family in times when the teenager experiences insecurities ${ }^{1,2}$.

The family may experience greater insecurity not only due to the new adaptations that the parents perform, but also because of the teenager's development, who faces progressive separation of the family ${ }^{2,3}$. In this process, the adolescent tends to question family values, which can lead to conflicts between parents and children ${ }^{2}$. Moreover, it is during adolescence that young people experience their first sexual relationships, and the significant adults play an important role in this process $\mathrm{s}^{4,5}$. They can provide support for adolescents so that they can experience their sexuality in a safe way or else repress it, hindering the choice of safe sexual behaviours ${ }^{4-6}$.

Thus, the way parents handle their relationships with their children influences the behaviours adopted by adolescents in different situations, including their sexual relationships ${ }^{7,8}$. Educational practices are strategies used

\footnotetext{
1 Graduada em Psicologia, Universidade Federal de Santa Maria (UFSM) - Santa Maria (RS), Brasil.

2 Mestre em Psicologia, Universidade Federal do Rio Grande do Sul (UFRGS) - Porto Alegre (RS), Brasil.

3 Doutoranda em Psicologia, UFRGS - Porto Alegre (RS), Brasil.

4 Mestre em Psicologia UFSM - Santa Maria (RS), Brasil.

5 Especialista em Criança e adolescente em situação de risco Centro Universitário Franciscano (UNIFRA) - Santa Maria (RS), Brasil.

6 Doutora em Psicologia Escolar e do Desenvolvimento, USP-SP, São Paulo, Brasil.

7 Docente do Programa de Pós-graduação em Psicologia UFSM - Santa Maria (RS), Brasil.

Corresponding author: Ana Cristina Garcia Dias. E-mail: anacristinagarciadias@gmail.com
}

Suggested citation: Delatorre MZ, Patias ND, Dias ACG. Educational practices and the relationship between parents and their pregnant and non-pregnant adolescent daughters. Journal of Human Growth and Development. 25(2): 141-150. DOI: http:// dx.doi.org/10.7322/jhgd.102992

Manuscript submitted: oct 22 2014. Accepted for publication: dec 192014. 
by parents to guide a child's behaviour, which aims to promote socialization through adopted standards of control and affection before circumstances occur that require hierarchy, discipline and decision making ${ }^{9}$. The educational practices are one way to study the relationship between parents and children since it can be both a risk factor or provide protection to the sexual behaviours presented by adolescents ${ }^{10}$. Parenting styles, in turn, are sets of attitudes from parents toward their children that represent the nature of their interactions. These attitudes are shaped by the effectiveness of parents' adopted practices in the socialization of their children. Parenting styles are different from educational practices, as it includes global aspects of these interactions, such as the affective context in which they occur'.

Several authors have been devoted to studying the practices and educational styles of parents, and many models have been developed. For example, Baumrind ${ }^{11}$ proposed the systematization of three parenting styles based on control strategies used by parents in parenting: permissive, authoritarian and authoritative. The permissiveness style is the acceptance of impulses, desires and actions of their children without the adoption of punitive practices. This style was subdivided by Maccoby and Martin ${ }^{12}$ as indulgent/ permissive and neglectful/absent. In contrast, the authoritarian control style seeks to shape, control and evaluate the child's behaviour, according to the standard of conduct considered correct by parents, usually with excessive control. The authoritative style is presented as a balanced parenting style in which control and limits, dialogue and affection are equally offered to children, providing an education that promotes development. In this parenting style, there exists directing behaviour, dialogue on social rules and incentives for discipline and autonomy.

According to Baumrind ${ }^{11}$, an effective education model requires flexibility and the prudent use of punishment in a context of responsibility and support between parents and children. In this sense, the authoritative style would be more appropriate, as it combines dimensions of behavioural control and dialogue on the rules and logic that involves its application ${ }^{11,12}$. This style would stimulate autonomic reasoning about issues, respect for adult authority and independent thinking ${ }^{13}$.

Another theoretical model was proposed by Hoffman ${ }^{14}$. This model comprises the relationship between parents and children based on power relations, centred on parental figures. Two disciplinary practices are used in the education of children: inductive and coercive practices. The first practice aims to promote the independence by noting the consequences of a child's or adolescent's behaviour, without the use of external sanctions and guilt. The coercive practices are based on the fear of external sanctions and the use of various forms of power, such as physical strength and deprivation. Effective practices would develop through the use of induction, in which parents would talk to their children and help them understand the importance of the results associated with each behaviour.
Finally, Gomide ${ }^{15}$ proposed another theoretical model that defines the parenting style as a set of educational practices used by parents in their relationship with their children. Among the seven educational practices that make up his parenting style model, two are positive (positive monitoring and moral behaviour) and five are negative (negligence, inconsistent punishment, negative monitoring, relaxed discipline and physical abuse). Positive monitoring refers to parental care and their knowledge about where there child is and what activities he or she is involved. Moral behaviour refers to the transmission of values that enables differentiation of what is right and what is wrong.

Among the negative practices, negligence includes the failure and absence of interactions without affection as well as inattention to the needs of children. The inconsistent punishment occurs when punishment or reinforcement of children's behaviour is given according to the mood of the parents, rather than the actions of their children. Negative monitoring refers to excessive supervision and repetitive instructions by the parents. Relaxed discipline happens when parents ignore children's circumvention of the rules laid down by them. Finally, physical abuse refers to parents' actions that hurt or cause pain to their children ${ }^{15}$.

It can be seen in all of the theoretical models mentioned that the parenting style influences the children's development. Several studies show that the authoritative/competent parental style and the inductive educational practices result in protection against various problems in children's and adolescent's behaviour, both externalizing and internalizing. On the other hand, authoritarian, lax and permissive parenting styles and coercive practices result in risk for children's development ${ }^{9,15-17}$.

In regards to children's sexual development, some studies show different relationships between parents' education practices and the adoption of risky sexual behaviour among adolescents ${ }^{10,18}$. It is worth noting that there is not only one definition in the literature for risky sexual behaviour (RSB); however, authors such as Huebner and Howell ${ }^{10}$ and Newman ${ }^{19}$ described these behaviours as the absence of condom use in sexual relations and/or involvement with multiple partners. CSR is also associated with the contraction of sexually transmitted diseases (STD) or the occurrence of an unwanted pregnancy.

One way to study the relationship between CSR and parenting practices is the comparison of these practices among pregnant and nonpregnant adolescents, assuming that the pregnancy is a result of CSR. For example, a study by Gomide et al. ${ }^{20}$, comparing the experiences of pregnant and non-pregnant adolescents in public and private schools, showed no differences between both groups. However, when the authors compared the group of pregnant adolescents in public schools to adolescents in private schools, a significantly higher level of relaxed discipline and maternal physical abuse among pregnant adolescents was identified. Also, there were higher incidences of physical abuse, negative 
monitoring, neglect and parental inconsistent punishment among pregnant adolescents. The authors argued that the socioeconomic status of parents may interfere in their disciplinary practices, which can adversely affect children's development. Therefore, the objective of this study was to describe the relationships between parenting practices and the occurrence of pregnancy in adolescents.

\section{METHODS}

This study has qualitative design, a study of multiple cases. ${ }^{21-23}$ Semi-structured interviews were conducted with five pregnant adolescents and six non-pregnant adolescents, between the ages 15 and 19 years. Data for the pregnant women were collected between September 2011 and February 2012, in a Basic Health Unit in a city in Rio Grande do Sul, Brazil. The adolescents without pregnancy experience were interviewed in May 2012 in a public school in the region of the same Basic Health Unit in order to ensure that informants belonged to the same social and cultural background.

The interviews contained questions about the pregnant teenager's relationship with her mother and father separately before and after the discovery of her pregnancy. However, for this study, only the answers which related to the time before the discovery of the pregnancy were considered. The interviews with the non-pregnant teenagers contained questions about their current relationships with their mother and father.

All survey participants also completed the Parental Styles Inventory (PSI). This instrument contains 42 phrases that correspond to the seven parenting practices ( 6 statements describing each practice) described by Gomide ${ }^{15}$. The positive monitoring (A) and moral behaviour (B) were the two educational practices considered positive. The inconsistent punishment (C), neglect (D), careless discipline $(E)$, negative monitoring $(F)$ and physical abuse (G) were the five practices considered negative.

This instrument was used with the goal of complementing the interviews in order to obtain more information about how the teenagers were managed by their parents in various everyday situations involving education, control and guidance. The statements included in the inventory helped identify the maternal and paternal parenting styles, classifying them in terms of their suitability or risk to their children's education. From this information, responses from both groups were compared (pregnant and non-pregnant adolescents) in order to verify if adolescents without pregnancy experience had more appropriate parenting styles than pregnant ones.

The adolescents were informed in advance of the study's objectives and procedures, and that participation was voluntary. After agreeing to participate, the responsible parties signed the Informed Consent (IC) containing all of the study's relevant information. It is noteworthy that the research project was approved by the Research
Ethics Committee of the Federal University of Santa Maria, under the Protocol 23081.013700/2010-97 and CAAE 0240.0.243.000-10, according to Resolution 196/96 of the Ministry of Health.

After the interviews were transcribed, content analysis ${ }^{22}$ was conducted to better understand participants' responses, to deepen their features and to highlight the most important moments. This technique consists of describing the content of the messages, using indicators to infer knowledge about the conditions in which such messages were produced. The analysis was developed in three stages: (1) pre-analysis, (2) material exploration and (3) treatment results interpretation and inference $^{22}$. At first, the information was organized with the main objective to systematize ideas, developing a flexible but accurate analysis plan. The first task performed at this time was to know the overall content of the interviews, leaving space for impressions and directions. "From this, there were text clippings in comparable categorization units (themes) for analysis.

Then, the material exploration occurred, which was based on the codification of transcribed interviews. Exploration was done according to the indicators analysis completed in the pre-analysis phase. The treatment phase and interpretation of the results was the synthesis and selection of results, inferences and their interpretation from the theoretical perspective adopted 22 .

The tabulation of the Parenting Styles Inventory data (PSI) was accomplished according to the guidelines in the manual. Each educational practice can have a maximum score of 12 points and a minimum of zero. To calculate the Parental Style Index (PSI), the points obtained in issues relating to positive practices were added $(A+B)$ (positive monitoring and moral behaviour) and then subtracted from the sum of the negative practice points $(C+D+E+F+G)$ (inconsistent punishment, neglect, relaxed discipline, negative monitoring and physical abuse). The PSI informs the prevalence of negative and positive educational practices, the presence of positive activities carried out by parents in the educational process of their children. When there was a greater presence of negative practices, the result was a negative parenting style. Conversely, there was a positive parenting style when there was a prevalence of positive educational practices. The PSI (parental style index) can vary from - 60, wherein there is an absence of positive practices, to +24 , which means the absence of negative practices and the presence of total positive ones.

After obtaining the PSI, the equivalent percentile of the PSI was obtained from the rules table, which indicates if the respondent was or was not at a level of risk. Thus, when the percentile was 1 to 25, there was risk in the parental style. Percentiles 30 to 50 reflected a positive parental style but were below the average. Percentiles 55 to 70 were also a good parenting style but were above average. Percentiles 75 to 99 revealed a great parenting style with a strong presence of positive parenting practices and an absence of negative practices ${ }^{23}$. 
The results were analyzed by reading the interviews as well as analyzing the participants' responses on the Parenting Styles Inventory (PSI) for all adolescents, who provided information about both parents (mother and father's practice). Information from the interviews was organized into categories, formed according to the topics proposed a priori related to the research objectives. Then, the results obtained in each group were compared in order to understand the similarities and differences present in both of their relationships with their parents. Four categories of analysis were identified: 1) relationship with the mother, 2) education received from the mother, 3 ) relationship with the father and 4) education received from the father.

The relationship of adolescents with their parents and their practices were compared between the experiences of pregnant adolescents to young people without pregnancy experience. The expectation was that both their relationships and the educational practices would be more positive in the group without pregnancy experience, reinforcing the idea that these two factors serve as protection against vulnerability to teenage pregnancy.

\section{RESULTS AND DISCUSSION}

\section{Relationship with mother}

Four of the five pregnant women described their relationship with their mother before pregnancy positively, using words like "cool," "partner" and "friend." Despite a positive relationship, two of these cases (Pregnant adolescents 3 and 5 ) had a certain detachment between mother and daughter. This was demonstrated when the quality of the relationship was evaluated by whether permission was given for the young teenager to go out, or when a difficult dialogue was revealed in some ways. This difficulty, especially in relation to the subject of sexuality, was also suggested by other studies conducted with pregnant and non-pregnant adolescents ${ }^{24-27}$.

Good, very good. (...) One is the friend of the other; helping each other (...) she was always a companion to me. (Pregnant adolescent 1,18 years)

I've never told things to my mom, you know. I've never had a very open relationship with her to tell her certain things. (...) Then in the evening when I arrived in the afternoon, we'd talk about several issues, but not about life, things like that. (Pregnant adolescent 3, 19 years)

"It was cool, sometimes she would not let me leave, I liked to go out, you know. Sometimes she let. (Pregnant adolescent 5, 15 years)"

In the group of pregnant women, one teenager reported a more troubled relationship with her mother before her pregnancy. These relationship problems were characterized by conflicts and fights, becoming closer after the knowledge of pregnancy.

It was less ... much less, I was much less close to her than now. (...) we argued a lot, you know, I bothered her a lot. We were always fighting as well. (Pregnant adolescent 2, 18 years)

The results of the Parenting Styles Inventory (PSI) of these pregnant teenagers showed that three of the women had a history of maternal parenting style that was "at risk" and two had a maternal parenting style classified as "good, but below the average" (proposed by the manual; see Table 1 ). These data reinforced the idea found in the interviews. Although the pregnant women described their relationship with their mother as positive, there may have been some difficulties in the mother-daughter relationship.

Table 1: Results achieved Inventory of Parental Styles of pregnant women, with regard to mother ${ }^{15}$

$\begin{array}{lcc} & \text { Percentile IEP Mother } & \text { Parental Style Mother } \\ \text { Pregnant 1 } & 30 & \text { Well below the average } \\ \text { Pregnant 2 } & 25 & \text { Parenting style risk } \\ \text { Pregnant 3 } & 20 & \text { Parenting style risk } \\ \text { Pregnant 4 } & 30 & \text { Well below the average } \\ \text { Pregnant 5 } & 5 & \text { Parenting style risk }\end{array}$

With regard to the five non-pregnant adolescents, there was a good relationship with the mother, indicated by the presence of dialogue, guidance and mutual respect between mother and daughter. There seemed to be, among them, a more open relationship, especially with regard to the mother-daughter dialogue as compared to the pregnant women surveyed. This information aligned with our initial expectations. Although both groups reported a positive relationship with their mothers, it was clear in the reports that there was a greater presence of dialogue between the non-pregnant adolescents and their mothers, whereas among pregnant women, the relationship between mother and daughter was described in a more superficial way.

Oh, we get along, she hears me, always listens to me, and she always respects my opinions (...) she always talks, she gives advice. Usually everything that I ask she answers me, right. (Non-pregnant adolescent 2,15 years)

It's very good. She cares enough that when I'm sad she holds me and asks what happened. (Non-pregnant adolescent 4, 17 years) 
Oh, my relationship with my mother is very good, because she is always willing to listen to me, she always helps me at everything (...) she always prefers that I do things in front of her instead of hiding things. (Nonpregnant adolescent 5, 15 years)

These adolescents without pregnancy experience also referred to a more distant relationship with her mother. However, there did not appear to be conflicts between mother and daughter, despite the relationship distance.

It's actually better with my father; I think that every girl finds it easier to talk to her father. (...) It seems that the mother always (...) does not hear much and wants to pay more attention to her, what she has to say. (Non-pregnant adolescent 1,17 years)"

Table 2 shows the results of the breast on the description of PSI young non-pregnant women.

According to the Parental Styles Inventory (PSI), two mothers of teenagers without pregnancy experience had a maternal parenting style "at risk", the other two had a parental style that was "good, above average" and a parenting style that was "good, but below average" and finally, one got the result of "great" (see Table 2 ). These data demonstrate that the childrearing practices were more positive among non-pregnant adolescents as compared to the young pregnant women.

Other studies have found similar differences in educational practices that have been experienced by both of these groups ${ }^{28,29}$. Patias et al. ${ }^{28}$, comparing the Inventory of Parenting Styles results of a pregnant adolescent with the results of a non-pregnant adolescent, found that the first adolescent did not receive a lot of mother supervision, while the second was constantly supervised and instructed on correct and incorrect behaviour. Pereira et al. ${ }^{29}$, in turn, compared a group of pregnant adolescents to a group of non-pregnant adolescents, demonstrating that the first received less protection and emotional support from both parents. These data are in line with the results of this study, which found more positive educational

Table 2: Results achieved the Parental Styles Inventory of adolescents in relation to non-pregnant mother ${ }^{15}$

$\begin{array}{lcc}\text { N-p adolescent 1 } & \text { Percentile IEP Mother } & \text { Parental Style Mother } \\ \text { N-p adolescent } 1 & 15 & \text { Parenting style risk } \\ \text { N-p adolescent 2 } & 90 & \text { Great parenting style } \\ \text { N-p adolescent 3 } & 65 & \text { Well above average } \\ \text { N-p adolescent } 4 & 25 & \text { Parenting style risk } \\ \text { N-p adolescent } 5 & 55 & \text { Well above average } \\ \text { N-p adolescent } 6 & 40 & \text { Well below the average }\end{array}$

practices among non-pregnant adolescents as compared to the pregnant adolescents.

However, maternal practices with risk were also found among adolescents without pregnancy experience. From this, it is suggested that, although many authors mention that negative parenting practices can make young people vulnerable to sexually risky behaviour ${ }^{10,18,19}$, a cause and effect relationship cannot be established between these practices and teenage pregnancy.

\section{Education received from the mother}

According to the responses from three of the pregnant adolescents, the form of punishment used by their mothers was name calling. Two of these participants ( 1 and 4 ) had a maternal PSI that was considered "good, but below average"; while another participant (Pregnant 2) showed a maternal parenting style described as "at risk" (see Table 1 ). The respondents' reactions in these situations varied from reflecting on their mistakes and their guilt from having committed them.

Look, she said it was wrong and called names. How did you feel? Bad. (...) I don't know. I felt that I did not do anything right, that ... that's it. (Pregnant adolescent 2, 18 years) Oh, she was totally outraged (...) she talked, fought, cried (laughs) also (...) after that happened I was really bad, because I thought: What I did or what I did not do. (Pregnant adolescent 4, 19 years)

The two other women ( 3 and 5 ) reported the use of physical punishment by their mothers, even in low intensity. One of the women reported that this happened only when she "was a minor" (younger), while the other said feeling angry front to a punishment. Both showed maternal parenting styles that were "at risk" (see Table 1). Similarly, Weber et al. ${ }^{17}$, in a study conducted with children and adolescents of the Paraná schools, showed that feelings of anger and sadness were common among children and adolescents, compared to the physical punishments received. Among adolescents without pregnancy experience, there was no mention of corporal punishment.

She punished. I could not leave. (...) Sometimes she hit me. But not much. And how do you feel in these situations? At the time, I felt angry, you know, I cannot explain. (Pregnant adolescent 5, 15 years)

In the group of non-pregnant teenagers, three of them also reported curses and/ or 
penalties as punishment. Of these, two (Teens 3 and 5) had maternal parenting styles as "good, above average," while the third (Adolescent 1) presented an PSI described as "at risk" (Table 2). In these three, two related feeling bad because they realized their mistake, while the third was satisfied by the way her mother educated.

Ah, when she's in a bad mood, it is difficult. It sometimes gets heavy, it makes me feel down. She speaks horrors too, it makes me very down. (Non-pregnant adoescent 2, 15 years)

If I do something wrong she takes my computer, or does not let me out, or does not let me see my boyfriend. (...) And how do you feel you with this her way of dealing with this? Oh, best thing. (Non-pregnant adolescent 5,15 years)

Although there were no indications about corporal punishment by the non-pregnant adolescents, we point out that these curses could be considered psychological abuse. According to the Ministry of Health ${ }^{30}$, psychological domestic violence is characterized by action or omission that causes, or is intended to cause, damage to selfesteem, identity or personal development.

Educational practices that include the use of punishments could enable the development of risky behaviours, both antisocial and sexual. A study by Xavier ${ }^{31}$ found that lower levels of CSR were associated with authoritative parenting style. On the other hand, adolescents who had higher scores on CSR were those whose parents had an indulgent or neglectful parenting style.

Studies in the United States show the same results patterns. ${ }^{10,31,32}$ A survey held with U.S. high school students found a positive relationship between the monitoring and communication of parents with teenagers and the lowest levels of youth involvement in $\mathrm{CSR}^{10}$. Similarly, a study of patients from a U.S. clinic dedicated to the care of adolescents demonstrated associations between parental monitoring and the use of hormonal contraception or dual protection (hormonal contraceptive and condom) for sexual relationships ${ }^{31}$. Finally, Tucker, Perreira and Halpern ${ }^{32}$, researching American teenagers, found associations between authoritarian and neglectful parenting styles and adolescent pregnancy.

These practices can influence the occurrence of pregnancy in adolescents in the sense that motherhood can represent both the acquisition of affection and the escape of a hostile family environment ${ }^{20}$, which failed to meet an adolescent's emotional needs ${ }^{24}$ and needs for autonomy ${ }^{33}$. The parenting practices may also influence the psychological well-being of adolescents and youth. Boeckel and Sarriera ${ }^{34}$, studying adult university students, found that $60.7 \%$ of the participants perceived the educational practices of parents as authoritative. These practices also functioned as predictors of psychological well-being of young people. From this, one can assume that pregnancy is less likely as a way to escape from a hostile or emotionally poor environment, when authoritative educational practices are used.

It is interesting to note that among the nonpregnant teenagers, three interviewees reported receiving mother's guidelines when they did something wrong. In some cases, this approach was accompanied by an explanation of the possible consequences of such behaviour, which led to the teenagers reflecting on the situation. This attitude, according to the literature, offers a good education for young people, as the internalization of morality is induced by a cognitive understanding of the consequences of their own acts. This understanding promotes autonomy and is the basis for future control of their conduct ${ }^{14}$.

"But then she talks, she never fights, she always tells me... 'do not do that, because it generates such, such and such result; if you do it again, then it will not work, your father will be angry. ' (...) There is no need for her to speak a second time. (Non-pregnant adolescent 2, 15 years)"

However, it is noteworthy that there were many PSI results for these three non-pregnant teenagers who reported using curses as punishment. Adolescents 2, 4 and 6 had a "great", an at "risk" and a "good, below average" maternal PSI, respectively (Table 2 ). This demonstrates that, despite the benefits mentioned in the literature, these practices should be accompanied by other positive educational practices, to be effective.

\section{Relationship with the father}

Pregnant adolescents reported having a proximity to the father and considered the relationship with him positive. The pregnant women also highlighted positive aspects such as the talk and the characteristics of a "playful" father.

I do not know, I think I was more attached, he was more playful, not that with my mother I was not, but with him I was much more. (Pregnant adolescent 1, 18 years)

Table 3: Results achieved Inventory of Parental Styles of pregnant women in relation to father ${ }^{15}$

$\begin{array}{lcc} & \text { Percentile IEP Paterno } & \text { Parental Style Paterno } \\ \text { Pregnant 1 } & 45 & \text { Well below the average } \\ \text { Pregnant 2 } & - & - \\ \text { Pregnant 3 } & 25 & \text { Parenting style risk } \\ \text { Pregnant 4 } & 35 & \text { Well below the average } \\ \text { Pregnant 5 } & 1 & \text { Parenting style risk }\end{array}$


Two of the adolescents reported some distance towards their father. One of them lived with her father, while the other predominantly had telephone contact with him. This last one (Pregnant 5), according to the PSI, also presented a parenting style that was "at risk" (Table 3 ). The first one (Pregnant 2 ) did not respond to the inventory because she reported that the relationship with her father did not exist.

I do not know because I do not live with my father, you know. He left when I was three, so no. (Pregnant adolescent 2, 18 years)

"It was very close, you know, we talked over the phone. (Pregnant adolescent 5, 15 years)"

In the case of one of the interviewed pregnant women, this figure of someone who was playful and funny was mixed with her father's rigidity and conservatism, making it difficult to dialogue with him. These features relate to what is suggested in the literature as an authoritarian father. This type of educational practice can undermine the autonomy of the child, and can cause feelings of hostility and opposition to the authority figure ${ }^{35}$. Interestingly, among the three women who reported having a good relationship with their fathers (pregnant adolescents 1, 3 and 4 ), only one pregnant woman presented a parenting style that was "at risk", according to the results of the IEP (Table 3 ).

My father was very playful, always, to this day he is very playful and funny, but my relationship with him, in this aspect of telling him the things, was very hard. (...) Because he was very angry and very conservative (...). (Pregnant adolescent 3, 19 years)
Similarly, non-pregnant adolescents reported having a good relationship with their parents, just pointing out some limitations when talking with their fathers, usually only talking about issues with their mothers. In the latter group, only one of the teenagers (4) had a father who's PSI was "at risk" (Table 4).

I'm very attached, it is well ... he's always in my house (...) except that my father is not one that I can talk about everything, so (...) It is not bad, but it seems that it is more superficial. (Non-pregnant adolescent 3, 16 years)

Comparing the results of the fathers' Parenting Styles Inventory in both groups, again, the educational practices were more positive among non-pregnant women, although a young woman with no pregnancy experience also had parental practices that were at risk. In this, similar results were found by Pereira et al. ${ }^{29}$, in which the paternal educational practices experienced by pregnant women were more negative than non-pregnant women. On the other hand, Patias et al. ${ }^{28}$, in a case study comparing a pregnant adolescent to a nonpregnant teenager, showed negative parental educational practices for both teenagers.

\section{Education received from the father}

Among pregnant women, the fathers' punishment appeared as a scolding, name-calling, without reference to physical punishment, similar to what happened with the mothers. Still, the fact has to be stressed again that psychological punishments can be as harmful as physical abuse. The paternal PSI of pregnant women was "good, but below average" (pregnant adolescent 1 and 4) and "risky" (pregnant adolescents 3 and 5) (Table 3). Psychological abuse can cause harm to

Table 4: Results achieved the Parental Styles Inventory of non-pregnant adolescents towards his father ${ }^{15}$

$\begin{array}{lcc} & \text { Percentile IEP Paterno } & \text { Parental Style Paterno } \\ \text { Teen 1 } & 65 & \text { Well above average } \\ \text { Teen 2 } & 90 & \text { Great parenting style } \\ \text { Teenager 3 } & 90 & \text { Great parenting style } \\ \text { Teenager 4 } & 25 & \text { Parenting style risk } \\ \text { Teenage 5 } & 30 & \text { Well below the average } \\ \text { Teenager 6 } & 30 & \text { Well above average }\end{array}$

the physical or mental health of children and adolescents, or impair their physical, mental or social development ${ }^{36}$. The reactions between the three respondents who reported this type of punishment was heterogeneous. One of the pregnant adolescents said she does not do wrong things so as to avoid the father's scolding. Another one reported indifference, while the third showed grief for doing something wrong. In fact, this type of punishment can increase emotions like anxiety and fear ${ }^{14}$. In children receiving corporal punishment, similar reactions such as sadness, fear, anger and anxiety can be found ${ }^{17}$.
"Oh, we did not because we knew (laughs). He had already warned before, so there was no time sometimes. There was that pressure, if I do, I'm going to take a parent scolding.

(Pregnant adolescent 1,18 years)

Oh, he was very angry. (...) He was angry, he swore, he spoke, said he could not have happened what happened, he was very angry. And you, how do you feel? Oh, I was the same way, you know, very upset because after you do that you think, right. (Pregnant adolescent 4, 19 years) 
One of the participants (5) reported that in addition to conversations when she did something wrong, her father eventually used physical punishment. The result of this paternal PSI for this pregnant adolescent was notable, which was classified as "at risk" (Table 3), and the score of the paternal percentile was only 1 . The adolescent referred to feeling a "bad feeling" when this happened. This reaction to corporal punishment is similar to those presented by other studies, which indicates sadness, anger, fear and anxiety. ${ }^{17,37,38}$. In these reactions, the use of this type of punishment to discipline children can bring negative influences to their development and influence a risk of antisocial and sexual behaviours occuring ${ }^{20}$. Finally, the fifth pregnant adolescent did not answer this question as she had no contact with his father.

Sometimes he would hit. And he had something else he did? No, just talking, when he did not beat me. How did you feel in this situation? When he hit me, I had a bad feeling. (Pregnant adolescent 5, 15 years)

Among adolescents without pregnancy experience, there were no references to corporal punishment. When the adolescents did something considered wrong, attitudes ranged from conversation, punishment and criticisms. As mentioned, the use of conversation and dialogue is positive as it promotes adolescents' reflection on the consequences of their own acts, promoting autonomy and serving as a basis for future control of their own behaviour ${ }^{14}$. In contrast, punishments and curses can damage the autonomy of the child, or cause hostile and feelings of opposition towards the authority figure $^{35}$. Three of the interviewees liked or felt certain their fathers' attitudes, while two related feeling bad about the situation.

When I, for example, had a fight, he cursed me, left me grounded. (...) And what would you think of him like that? I think that's right because here is no use in beating me. (Nonpregnant adolescent 5, 15 years)

If I do something wrong he calls me to talk. Sometimes he prefers only the two of us to talk, then he starts asking me what I did, what I should not done, that, that, well, always like that. And how do you feel you? Oh, bad, you know, because I do not like to hurt my father, don't like to leave him upset. (Non-pregnant adolescent 1, 17 years)

\section{REFERENCES}

1. Wagner A, Tronco C, Armani AB. Os desafios da família contemporânea: revisitando conceitos. In: Wagner A, (org). Desafios psicossociais da família contemporânea: pesquisa e reflexões. Porto Alegre: Artmed; 2011; p. 19-35.
Among the young people who reported that the conversations were used for conflict resolution, one had a "good, above average" (Adolescent 1), two had a "great" (adolescent 2 and 3 ) and one had an "of risk" paternal PSI (Adolescent 4). Another teenager (5) who reported receiving punishment and swearing had a "good, but below average" paternal PSI and, finally, the teenager (6) who heard her father curse had a "good, above average" paternal PSI (Table 4). Again, inventory results partially support the information obtained in interviews. Adolescents who resolved conflicts through dialogue, except for one, had more positive scores. However, the positive scores of teenagers who lived with practices identified by the literature as harmful, demonstrate the importance of considering the education received by children as a whole, not just in isolated aspects.

Social vulnerability of the family, for example, can play an important role in this regard. Macedo, Kublikowski and Berthoud ${ }^{39}$, analysing a sample of parents of São Paulo adolescents, found that socially vulnerable parents are stiffer in their education and in imposing rules to their children. Less vulnerable parents are more flexible and use educational practices more oriented to autonomy. The authors emphasized that the parents of both groups considered that they are successful in the task of educating their children.

It has to be stressed that this study is important because it is necessary to understand the factors that contribute to teenage pregnancy, as it is a public health problem ${ }^{40}$. Teen pregnancies can cause youths' greater financial dependence on their parents, abandonment of their studies and freedom restrictions due to the lack of child care $^{41}$. In view of these impasses and the fact that, often, the desire to be a mother emerges from a hostile family environment as an escape ${ }^{20}$, it is essential to build interventions to prevent this type of established environments for adolescents. In addition, domestic violence contributes not only to vulnerability for pregnancy, but also to the development of antisocial behaviours ${ }^{20}$, various risky behaviours towards health, and the development of chronic diseases ${ }^{36}$.

In conclusion, maternal educational practices, but not paternal, seem to be associated with the occurrence of pregnancy in adolescents. Thus, the study of parental education and guidance for their children and adolescents can serve as an important tool to prevent these risks. It should be noted that teenage pregnancy is a complex phenomenon, with several factors contributing to its occurrence ${ }^{42}$ and development ${ }^{43}$, with family relationships being only one aspect to be studied and shaped.

2. Stengel M. O exercício da autoridade em famílias com filhos adolescentes. Psicol Rev. Belo Horizonte: 2011; 17(3): 502-21. DOI: http:// dx.doi.org/10.5752/P.1678-9563. 2011v17n3p502

3. Mota CP, Rocha M. Adolescência jovem e adultícia: crescimento pessoal, separaçãoindivuduação e o jogo das relações. Psic Teor 
Pesq . 2012; 28(3): 357-366. DOI:http// dx.doi.org/10.1590/S0102-37722012000 300011

4. Rodgers KB, McGuire, JK. Adolescent sexual risk and multiple contexts: interpersonal violence, parenting, and poverty. J Interpers Violence. 2012; 27(11): 2091-2107. DOI: http//dx.doi.org/10.1177/08862605114321 $48^{\prime \prime}$

5. Oberlander SE, Wang $\mathrm{Y}$, Thompson R, Lewis $\mathrm{T}$, Proctor LJ, Isbell $\mathrm{P}$, et al. Childhood maltreatment, emotional distress, and early adolescent sexual intercourse: multiinformant perspectives on parental monitoring. J Fam Psychol. 2011; 25(6): 88594. DOI: http://dx.doi.org/10.1037/a0025423

6. Ximenes Neto FRG, Dias MSA, Rocha J, Cunha ICKO. Gravidez na adolescência: motivos e percepções de adolescentes. Rev Bras Enferm. 2007; 60(3): 279-85. DOI: http:// d x.doi . org/10.1590/S003471672007000300006

7. Faler CS, Câmara SG, Aerts DRGC, Alves GG, Béria JU. Family psychosocial characteristics, tobacco, alcohol, and other drug use, and teenage pregnancy. Cad Saúde Pública. 2013; 29(8): 1654-63. DOI: http://dx.doi.org/ 10.1590/0102-311X00107812

8. Lima FCA, Jesus FB, Martins CBG, Souza SPS, Matos KF. A experiência e atitudes de adolescentes frente a sexualidade. Mundo Saúde. 2013; 37(4): 385-93.

9. Patias ND, Siqueira AC, Dias ACG. Práticas educativas e intervenção com pais: a educação como proteção ao desenvolvimento dos filhos. Mudanças. Psicol Saúde. 2013; 21(1): 29-40. DOI: http://dx.doi.org/10.15603/ 2176-1019/mud.v21n1p29-40

10. Huebner AJ, Howell LW. Examining the relationship between adolescent sexual risktaking and perceptions of monitoring, communication, and parenting styles. J Adolesc Health. 2003; 33(2): 71-8. DOI: http://dx.doi.org/10.1016/S1054$139 \times(03) 00141-1$

11. Baumrind D. Effects of authoritative parental control on child behavior. Child Dev. 1966; 37(4): 887-907. DOI: http://dx.doi.org/ $10.2307 / 1126611$

12. Maccoby EE, Martin JA. Socialization in the context of the family: Parent - child interaction. In: Hetherington EM, editor. Mussen manual of child psychology. 4th ed. New York: Wiley; 1983. p. 1-102.

13. Baumrind D. The discipline encounter: contemporary issues. Aggress Violent Behav. 1997; 2(4): 321-35. DOI: http://dx.doi.org/ 10.1016/S1359-1789(97)00018-9

14. Hoffman ML. Moral internalization, parental power and the nature of parent child interaction. Dev Psychol. 1975; 11(2): 22839. DOI: http://dx.doi.org/10.1037/h0076463

15. Gomide PIC. Inventário de Estilos Parentais: modelo teórico, manual de aplicação, apuração e interpretação. Petrópolis: Vozes; 2006.

16. Patias ND, Siqueira AC, Dias ACG. Bater não educa ninguém! Práticas educativas parentais coercitivas e suas repercussões no contexto escolar. Educ Pesqui. 2012; 38(4): 981-96. DOI: http://dx.doi.org/10.1590/S151797022012000400013

17. Weber LND, Viezzer AP, Brandenburg O J. O uso de palmadas e surras como prática educativa. Estud Psicol. Natal: 2004; 9(2): 227-37. DOI: http://dx.doi.org/10.1590 S1413-294X2004000200004

18. Patias ND, Gabriel MR, Dias ACG. A família como um dos fatores de risco e de proteção nas situações de gestação e maternidade na adolescência. [cited 2015 Jun 17] Available from: http://pepsic.bvsalud.org/pdf/epp/ v13n2/v13n2a11.pdf.

19. Newman K, Harrison L, Dashiff C, Davies S. Relações entre modelos de pais e comportamentos de risco na saúde do adolescente: uma revisão integrativa da literatura. Rev Latino-Am. Enfermagem. 2008; 16(1): 14250. DOI: http://dx.doi.org/10.1590/S010411692008000100022

20. Gomide PIC, Millan DC, Boaron M, Rasquim S, Czeczko NG, Ribas CPM. Práticas parentais educativas e gravidez na adolescência. Rev Med Paraná. 2005; 63(2): 32-6.

21. Yin RK. Estudo de caso: planejamento e método. Porto Alegre: Bookman; 2005; p.212.

20. Bardin L. Análise de conteúdo. Lisboa: Edições; 2006. p. 27-50.

23. Sampaio ITA, Gomide PIC. Inventário de Estilos Parentais (IEP) - Gomide (2006) Percurso de Padronização e Normatização. Psicol Argum.. 2007; 25(48): 15-26.

24. Dadoorian D. Gravidez na adolescência: um novo olhar. Psicol Ciênc Prof. 2003; 23(1): 8491. DOI: http://dx.doi.org/10.1590/S141498932003000100012

25. Savegnago SDO, Arpini DM. Conversando sobre sexualidade na família: olhares de meninas de grupos populares. Cad Pesqui. 2013; 43(150): 924-47. DOI: http:// d x.doi.org/10.1590/S010015742013000300010

26. Dias ACG, Gomes WB. Conversas em família, sobre sexualidade e gravidez na adolescência: percepção das jovens gestantes. Psicol Reflex Crít. 2000; 13(1): 109-25. DOI: http:/ / dx.doi.org/10.1590/S0102 79722000000100013

27. Witter GP, Guimarães EA. Percepções de adolescentes grávidas em relação a seus familiares e parceiros. Psicol Ciênc Prof. 2008; 28(3): 548-57. DOI: http://dx.doi.org/ 10.1590/S1414-98932008000300009

28. Patias ND, Dias ACG, Mahl FD, Fiorin PC. Práticas educativas parentais e gestação na adolescência: comparando as experiências da gestante adolescente e da adolescente sem experiência de gestação. Adolesc Saúde. Rio de Janeiro: $2012 ;$ 9(1): 18-24.

29. Pereira AI, Canavarro MC, Cardoso MF, Mendonça D. Relational factors of vulnerability and protection for adolescent pregnancy: a crosssectional comparative study of portuguese pregnant and nonpregnant adolescents of low socioeconomic status. Adolescence. 2005; 40(159): 655-71.

30. Silva LL, Coelho EBS, Caponi, SNC. Violência silenciosa: violência psicológica como condição da violência física doméstica. Interface. Botucatu: 2007; 11(21): 93-103. DOI: http:/ /dx.doi.org/10.1590/S1414-32832007 000100009

31. Backer JG, Rosenthal SL, Leonhardt D, Kollar LM, Succop PA, Burklow KA, et al. Relationship between perceived parental monitoring and young adolescent girl's sexual and substance use behaviors. J Pediatr Adolesc Gynecol. 
$1999 ; 12(1): 17-22$. DOI: http://dx.doi.org/ 10.1016/S1083-3188(00)86615-2

32. Tucker C, Perreira K, Halpern CT. Parenting strategies and teenage pregnancy. [cited 2015 Jun 17] Available from: http://paa2011. princeton.edu/papers/

33. Hoga LAK, Borges ALV, Reberte LM. Razões e reflexos da gravidez na adolescência: narrativas dos membros da família. Esc Anna Nery. 2010; 14(1): 151-7. DOI: http://dx.doi.org/ 10.1590/S1414-81452010000100022

34. Boeckel MG, Sarriera JC. Estilos parentais, estilos atribucionais e bem-estar psicológico em jovens universitários. Rev Bras Crescimento Desenvolv Hum. 2006; 16(3): 53-65.

35. Hoffman ML. Power assertion by the parent and its impact on the child. Child Dev. 1960; 31(1): 129-43.DOI: http://dx.doi.org/ $10.2307 / 1126389$

36. World Health Organization (WHO) and International Society For Prevention Of Child Abuse And Neglect. Preventing child maltreatment: a guide to taking action and generating evidence. World Health Organization; Geneva: 2006; p.7-16.

37. Mello ACC. Kit respeitar: enfrentamento à violência contra crianças e adolescentes: criar respeitando: guia para pais e responsáveis. São Paulo: Fundação Orsa; 2008. p.24-26.
38. Weber LND. Estilos e práticas parentais e sinais de depressão em adolescentes brasileiros. Rev Psicol. 2013; 1(1): 217-26.

39. Macedo RMS, Kublikowski I, Berthoud CME. Valores positivos e desenvolvimento do adolescente: uma perspectiva dos pais. Rev Bras Crescimento Desenvolv Hum. 2006; 16(2): 38-52.

40. Moreira TMM, Viana DS, Queiroz MVO, Jorge MSB. Conflitos vivenciados pelas adolescentes com a descoberta da gravidez. Rev Esc Enferm USP. 2008; 42(2):312-20. DOI: http:/ / dx.doi.org/10.1590/S008062342008000200015

41. Andrade PR, Ribeiro CA, Silva CV. Mãe adolescente vivenciando o cuidado do filho: um modelo teórico. Rev Bras Enferm. 2006; 59(1): 30-5. DOI: http://dx.doi.org/10.1590/S003471672006000100006

42. Dias ACG, Teixeira MAP. Gravidez na adolescência: um olhar sobre um fenômeno complexo. Paidéia (Ribeirão Preto). 2010; 20(45): 123-31. DOI: http://dx.doi.org/10.1590/ S0103-863X2010000100015

43. Oliveira-Monteiro NR, Negri M, Fernandes AO, Nascimento JOG, Montesano FT. Gravidez e maternidade de adolescentes: fatores de risco e de proteção. Rev Bras Crescimento Desenvolv Hum. 2011; 21(2): 198-209.

\section{RESUMO}

Introdução: A família é um importante ambiente de socialização dos filhos que possui influência sobre os comportamentos dos adolescentes, podendo se constituir como fator de risco e ou de proteção ao desenvolvimento dos mesmos. Objetivo: Descrever as relações estabelecidas entre práticas educativas parentais e a ocorrência da gestação na adolescência.

Método: Foram utilizadas entrevistas semiestruturadas com 11 adolescentes (5 gestantes e 6 não-gestantes) de 15 a 19 anos e aplicado o Inventário de Estilos Parentais - IEP - referente às práticas maternas e paternas, nas adolescentes. As entrevistas foram submetidas a uma análise de conteúdo temática. Já o IEP foi levantado segundo proposta do manual. Resultados: Constatou-se que há diferenças e semelhanças nos relacionamentos das adolescentes gestantes e não gestantes com seus pais. O relacionamento com a mãe parece ser mais positivo entre as jovens sem experiência de gravidez. Também foram observadas mais práticas educativas negativas maternas entre as gestantes, comparadas às não gestantes. Já o relacionamento com o pai foi semelhante entre os dois grupos, da mesma forma que as práticas educativas paternas foram negativas tanto entre as jovens gestantes quanto entre as não gestantes. Conclusão: As práticas educativas maternas, mas não as paternas, parecem estar associadas à ocorrência da gestação na adolescência.

Palavras-chave: educação, pais, adolescentes, práticas educativas parentais, gravidez. 